\title{
Immunosuppressive Effect of Prodigiosin on Murine Splenocyte and Macrophages
}

\author{
Jung-Eun HuH', Hyun-Jung Koo', Kyung-Ho, Kıм', Joung-Han Yıм², \\ Hong-Kum LeE ${ }^{2}$, Eun-Wha SoHN ${ }^{3}$, and Suhkneung Pyo ${ }^{1}$ \\ ${ }^{1}$ Devision of Immunopharmacology, College of Pharmacy, Sungkyunkwan University, Suwon, Kyunggi-do, 440-746, Republic of Korea. \\ ${ }^{2}$ Polar BioCenter, Korea Polar Research Institute, KORDI, Incheon, 406-840, Republic of Korea \\ ${ }^{3}$ Department of Pharmacognosy and Material development, Kangwon National University, Samcheok city, \\ Kangwon-do, 245-711, Republic of Korea
}

(Received October 24, 2008; Revised November 19, 2008; Accepted November 21, 2008)

\begin{abstract}
Prodigiosin was isolated from marine bacteria Hahella chejuensis which has been recently discovered from Marado, Cheju Island, Republic of Korea. Immunosuppressive properties have been reported for prodigiosin members such as undecylprodigiosin, metacycloprodigiosin, prodigiosin, and its synthetic analogue PNU156804 (PNU). However, the effect of this agent on the function of macrophage and splenocyte has not been characterized in detail. In the present study, we examined the effects of prodigiosin for its ability to alter the function of murine macrophage and NK cell, and the proliferation of splenocytes. When thioglycollate-elicited macrophages pre-exposed to prodigiosin $(1-50 \mathrm{ng} / \mathrm{ml})$ were stimulated with LPS/IFN- $\gamma$, pretreatment with prodigiosin resulted in the inhibition of tumoricidal activity of macrophage in a concentration-dependent manner. Tumoricidal activity of NK cell was also inhibited by prodigiosin. Moreover, we found that prodigiosin was able to cause a dose-dependent inhibition of murine lymphocyte responsiveness to Con A and LPS although T-mitogenic response was the more sensitive one. Taken together, the present results point out that prodigiosin has a suppressive effect on the mitogen-induced proliferation of murine lymphocytes and the function of macrophage and NK cell.
\end{abstract}

Keywords : Hahella chejuensis, Prodigiosin, Immunosuppression, Macrophages, Splenocyte

\section{INTRODUCTION}

There has been increasing interest in the discovery and development of novel pharmaceuticals from marine microorganisms that have the same or better immunosuppressants accompanied by less side effects. Recently, the only species of the genus, Hahella chejuensis, was isolated from the coastal marine sediment of the southernmost island in Korea and the complete genome sequence of H.chejuensis in its class was determined (Jeong et al., 2005). This bacterium produces abundant extracellular polysaccharides and prodigosin (Lee et al., 2001). Prodigiosins are a family of natural red pigments containing three pyrrole rings produced by $S$. marcescens, Pseudomonas magnesiorubra, Vibrio psychro-

\footnotetext{
${ }^{*}$ Corresponding author

Tel: +82-31-290-7713 Fax: +82-31-292-8800

E-mail: snpyo@skku.edu
}

erythrus and other bacteria. Some members of this family, including prodigiosin, have been suggested to have immunosuppressive activity, which suppress cytotoxic $T$ cells by inhibition of acidification of intracellular organelles without affecting B cell-mediated immune functions, different from that of the other well known immunosuppressors such as cyclosporine A, FK506 and rapamycin (Kataoka et al., 1995; Songia et al., 1997; Pandeya et al., 2003). However, the effect of prodigiosin on the function of macrophage, Natural killer (NK) cells and splenocyte is less well understood.

Macrophages and NK cells in peripheral blood play important roles in the antigen-independent initial host defense system against infection with various microbes. NK cells are an important component of the innate immune system and mediate the cytolytic activities against tumor and virus-infected targets. In addition to the cytotoxic activity, there are increasing indications that NK cells can secrete a variety of cytokines and cytotoxic fac- 
tors (Herberman and Callewaert, 1985). Macrophages have been shown to be important components of the host defenses against bacterial infections and murine tumor cells (lymphoma and mastocytoma) (Hahn et al., 1981; Verstovsek et al., 1992).

In the present study, we determined the effect of prodigiosin on the proliferation of lymphocyte and the function of murine macrophages and natural killer cells (NK) in order to gain a further insight into the mechanisms whereby this compound may mediate its immunosuppressive action in vivo.

\section{Materials and Methods}

\section{Isolation of prodigiosin}

Prodigiosin was extracted with a mixture of methanol/ $1 \mathrm{~N} \mathrm{HCl}(24: 1, \mathrm{v} / \mathrm{v})$ from the supernatant of H.chejuensis culture which was grown on Marine Broth (Difco) for 24$48 \mathrm{~h}$ at $300 \mathrm{C}$ with vigorous shaking, as previously described (Jeong et al., 2005). Red-colored fraction was purified through high-performance liquid chromatography (LC). Following LC using acetonitrile and water (with $0.1 \%$ formic acid) as the mobile phase at a flow rate of $0.2 \mathrm{ml} / \mathrm{min}$, ESI-MS was carried out with a Finnigan LCQ Advantage MAX ion trap mass spectrometer equipped with a Finnigan electrospray source. To determine the molecular structure, $1 \mathrm{H} \mathrm{NMR} \mathrm{(CD3OD,} 300 \mathrm{MHz}$ ) and 13C NMR (CD3OD, $75 \mathrm{MHz}$ ) analyses were performed, resulting in the raw data of $6.94(\mathrm{~m}, 1 \mathrm{H}), 6.71(\mathrm{~m}, 1 \mathrm{H})$, $6.66(\mathrm{~s}, 1 \mathrm{H}), 6.39(\mathrm{~s}, 1 \mathrm{H}), 6.21(\mathrm{~m}, 1 \mathrm{H}), 6.01(\mathrm{~s}, 1 \mathrm{H}), 3.89$ $(\mathrm{s}, 3 \mathrm{H}), 2.37(\mathrm{t}, 2 \mathrm{H}), 2.27(\mathrm{~s}, 3 \mathrm{H}), 1.53(\mathrm{~m}, 2 \mathrm{H}), 1.33(\mathrm{~m}$, $4 \mathrm{H}), 0.90$ (t, 3H) ( ${ }^{1} \mathrm{H}$ NMR) and 169.6, 160.2, 141.0, $135.8,129.9,129.2,125.1,123.0,120.6,115.9,113.1$, $110.9,95.9,58.9,32.7,31.8,26.6,23.6,14.4,11.5$ (13C NMR).

\section{Mice, chemicals and reagents}

The C57BL/6 male mice (6-8 weeks old, $17-21 \mathrm{~g}$ ) were obtained from Charles River Breeding Laboratories (Atsugi, Japan). Unless otherwise indicated, all the chemicals were purchased from Sigma Chemical Co. (St Louis, MO). The RPMI 1640 medium and fetal bovine serum were purchased from GIBCO (Grand Island, NY). All tissue culture reagents, the thioglycollate broth and prodigiosin were assayed for any endotoxin contamination using the Limulus lysate test (E-Toxate kit, Sigma) and the level of endotoxin was found to be $<10 \mathrm{pg} / \mathrm{ml}$.

\section{Isolation of inflammatory peritoneal macrophages}

The thioglycollate-elicited peritoneal-exudate cells were obtained from C57BL/6 male mice (6-8 weeks old, 17-21 g) after they were given an intraperitoneal injection of 1 $\mathrm{ml}$ Brewer Thioglycollate broth $(4.05 \mathrm{~g} / 100 \mathrm{ml}$ ) (Difco Laboratories, Detroit, ML) followed by a lavage of the peritoneal cavity with $5 \mathrm{ml}$ of medium 3-4 days later. The cells were washed twice and resuspended in RPMI-1640 containing $10 \%$ heat-inactivated fetal bovine serum (FBS), penicillin (100 IU/ml) and streptomycin $(100 \mu \mathrm{g} /$ $\mathrm{ml})$. The macrophages were isolated from the peritoneal exudate cells using the method described by Um et al. (2002). The peritoneal exudate cells were seeded on teflon-coated petri dishes $(100 \times 15 \mathrm{~mm})$ at densities of 5 $6 \times 10^{5}$ cells $/ \mathrm{cm}_{2}$ and the macrophages were allowed to adhere for $2-3 \mathrm{~h}$ at $37^{\circ} \mathrm{C}$ in a $5 \% \mathrm{CO}_{2}$ humidified atmosphere. Teflon-coated petri dishes were prepared by spraying them with aerosolized teflon (Fisher Scientific, Pittsburgh, PA), which was followed by sterilization using ultraviolet light for $3 \mathrm{~h}$. The non-adherent cells were removed by washing the dishes twice with a $10 \mathrm{ml}$ prewarmed medium and incubating the dishes for $10 \mathrm{~min}$ at $4^{\circ} \mathrm{C}$. The supernatants were then carefully removed and discarded, and the plates were washed once with a prewarmed Dulbecco's Phosphate Buffered Saline solution (PBS) (GIBCO). Cold PBS (15 ml) containing 1.5\% FBS was then added, which was followed by the addition of $0.3 \mathrm{ml}$ of $0.1 \mathrm{M}$ EDTA ( $\mathrm{pH} 7.0)$. The plates were incubated for $15 \mathrm{~min}$ at room temperature and the macrophages were removed by rinsing the plates 10 times using a $10 \mathrm{ml}$ syringe. The viability of the detached cells was assessed by trypan blue exclusion and the proportion of macrophages was determined after cytoplasmic staining with acridine orange using fluorescence microscopy. More than $95 \%$ of the cell preparations were viable and contained $>95 \%$ macrophages.

\section{MTT proliferation assay}

A modification of the method of Mosmann et al. (1983) was used. Spleens were aseptically removed and dissociated into a single-cell suspension in culture medium. The concentration was adjusted to $2 \times 10^{6} \mathrm{cells} / \mathrm{ml}$. Mitogenic stimulation was done as follows, $5 \times 10^{5}$ cells per well in a total volume of $50 \mu$ were incubated in the absence (control) or presence of mitogens. Additions (50 $\mu$ l) were: concanavalin $A$ (Con A) for $T$ cell activation at 4 $\mu \mathrm{g} / \mathrm{ml}$; and lipopolysaccharide (LPS) for B cell activation at $10 \mu \mathrm{g} / \mathrm{ml}$. After an incubation period of $48 \mathrm{~h}$, the enzyme activity of viable cells was measured by addition of 3-(4,5-dimethylthiazolyl-2)-2,5-diphenyl tetrazolium bromide (MTT) to each well. After $4 \mathrm{~h}$ additional incubation and the dissolution of the crystals of MTT, the absorption 
was measured at $570 \mathrm{~nm}$ using a Molecular Devices microplate reader (Menlo Park, CA).

\section{Assessment of cell viability}

To evaluate a possible toxicity of prodigiosin against splenocytes and macrophages, cells were seeded at a concentration of $1 \times 10^{5}$ cells/well in 96-well tissue culture plates and treated with various concentrations of prodigiosin for $2 \mathrm{~h}$. Cell viability was measured by the trypan blue exclusion assay

\section{Macrophage-mediated cytotoxicity}

The assay for macrophage cytotoxicity was based on an assay described elsewhere (Bae et al. 2006). Briefly, the macrophages $\left(1 \times 10^{5}\right.$ cells/well) were plated into 96 well microtiter plates and preincubated with various concentrations of prodigiosin for $2 \mathrm{~h}$ at $37^{\circ} \mathrm{C}$ in a $5 \% \mathrm{CO}_{2}$ incubator. The macrophages were then treated with IFN- $\gamma$ $(100 \mathrm{U} / \mathrm{ml})$ combined with LPS $(1 \mu \mathrm{g} / \mathrm{ml})$. The macrophages were washed with RPMI-FBS to remove the CRME and co-incubated with the B16 melanoma cells (ATCC, Rockville, MD) (1.0×104/wells; an initial effector:target cell ratio of $10: 1$ ) at $37^{\circ} \mathrm{C}$ in a $5 \% \mathrm{CO}_{2}$ incubator. The cell density was then assessed by incubating the cells with $25 \mu \mathrm{g} / \mathrm{ml}$ MTT [3-(4,5-dimethylthiaozle-2-yl)-2,5diphenyl-tetrazolium bromide] for a further $4 \mathrm{~h}$. The formazan produced was dissolved in dimethyl sulfoxide and the optical density of each well was determined at a wavelength of $540 \mathrm{~nm}$ using a molecular device microplate reader (Menlo Park, CA). The cytotolytic activity is expressed as the percentage tumor cytotoxicity as follows:

$\%$ Cytotoxicity $=\{1-$ O.D. of $[($ target + macrophages $)$

- macrophages] / O.D. of target (nontreated) $\} \times 100$

\section{Assessment of NK cell cytotoxicity}

The NK cell cytotoxicity was determined using a standard ${ }^{51} \mathrm{Cr}$ release assay (Kim et al., 2003). Spleen cells were tested as effector cells and YAC-1 mouse lymphoma cells (ATCC) were used as the target cells labeled with a sodium ${ }^{51} \mathrm{Cr}$-chromate solution (Amersham, Arilington Height, IL). Splenocytes were pretreated with various concentrations of prodigiosin for $2 \mathrm{~h}$ at $37^{\circ} \mathrm{C}$ in a $5 \%$ $\mathrm{CO}_{2}$ incubator. Cells were then treated with IL-2 (100 U/ $\mathrm{ml}$ ). The NK cell assays were carried out in 96-well v-bottom plates at effector/target cell ratios 10:1, 50:1 and 100:1 with $1 \times 10^{4}$ of the target cells in a final well volume of $200 \mu \mathrm{l}$ for $6 \mathrm{~h}$ at $37^{\circ} \mathrm{C}$ in a $5 \% \mathrm{CO}_{2}$ humidified incubator. The specific release of ${ }^{51} \mathrm{Cr}$ by the YAC-1 target cells reflected the natural cytotoxic activity of the NK cells, and was calculated as follows: \% cytotoxicity $=[(E-S) /(T-$ S) $] \times 100$

where $\mathrm{E}$ is the activity of the ${ }^{51} \mathrm{Cr}$ released from the target cells in the presence of effector cells, $S$ is the activity of ${ }^{51} \mathrm{Cr}$ released spontaneously from the target cells alone under identical conditions. $T$ is the maximum activity of the ${ }^{51} \mathrm{Cr}$ released when all the target cells were destroyed.

\section{Statistical analysis}

Each result is reported as means \pm S.E.M. Two-way analysis of variance was used for analysis of differences among groups and the significant values are represented by an asterisk ( $\left.{ }^{*} \mathrm{p}<0.05\right)$.

\section{RESULTS AND DISCUSSION}

Since lymphocyte proliferation is a crucial event in the activation cascade of both cellular and humoral immune responses, we examined whether prodigiosin affects $T$ and B cell proliferation. Splenocytes from mice were pretreated with various concentrations $(1-50 \mathrm{ng} / \mathrm{ml})$ of prodigiosin for $2 \mathrm{~h}$ prior to stimulation with the mitogens Con $\mathrm{A}$ (a T-cell-specific mitogen) or LPS (a B-cell-specific mitogen). Treatment of splenocytes with prodigiosin reduced the proliferation in a concentration-dependent manner (Fig. 1a). Similar results were seen when splenocytes were treated with prodigiosin and concurrently stimulated with mitogens (Fig. 1b). The antiproliferative effect of this prodigiosin was not due to a toxic effect on lymphocytes, since prodigiosin at the highest concentration used did not cause any significant loss of cell viability (data not shown).

Con A and LPS were shown to strongly affect the proliferation of the two lymphocyte populations. It can be noted that the suppressive effect of prodigiosin was significantly stronger against the mitogenic response induced by Con A than against that induced by LPS. These data which lead us to conclude that prodigiosin inhibited T-lymphocytes preferentially are in keeping with the previous notion that T-lymphocytes proliferation was suppressed by prodigiosin members from various microorganisms (Nakamura et al. 1986: Pandeya et al. 2003).

In the next set of experiment, the cytolytic capacity of the NK cells was measured using a ${ }^{51} \mathrm{Cr}$ releasing assay at different E:T ratios. The pretreatment with prodigiosin resulted in a significant suppression in NK activity compared with the control at E:T ratio of 10:1 (Fig. 2a). The effect of prodigiosin on the NK activity was also exam- 
(A)

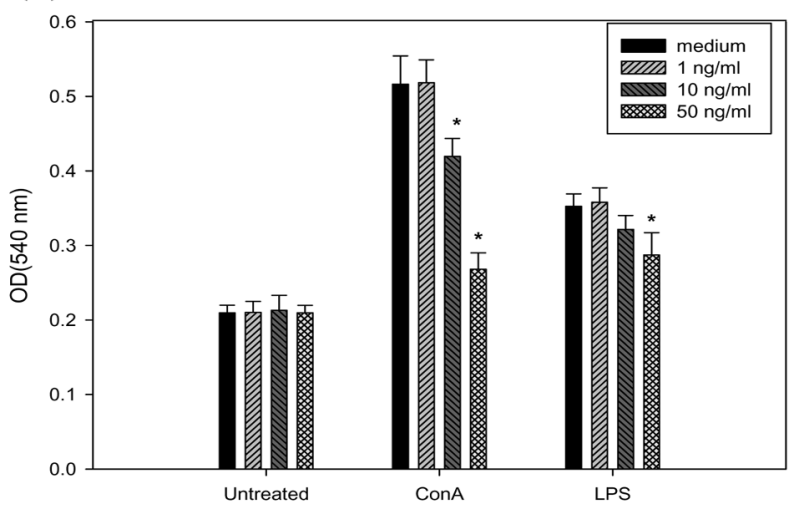

(B)

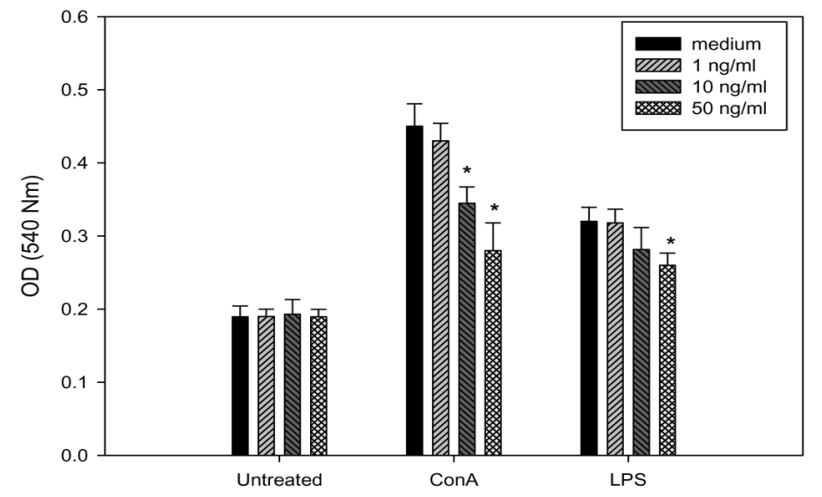

Fig. 1. Effects of prodigiosin on splenocyte proliferation. Splenocytes from mice were treated with Con A $(4 \mu \mathrm{g} / \mathrm{ml})$ or LPS $(10 \mu \mathrm{g} / \mathrm{ml})$. Prodigiosin was added $2 \mathrm{~h}$ prior to mitogens $(A)$ or concurrently with mitogens $(B)$ and the cells were further incubated for $48 \mathrm{~h}$. Proliferation was measured by MTT assay. Data are presented as the mean \pm SEM of quintuplicates from a representative experiment. $* \mathrm{P}<0.05$ : significantly different from control (no treatment). Experiments were repeated 3 times.

ined at $\mathrm{E}: \mathrm{T}$ ratios of 50:1 and 100:1. Culturing the splenocytes with prodigiosin for $2 \mathrm{~h}$ resulted in the suppression of NK cell activity, which was dose dependent. $10 \mathrm{ng} / \mathrm{ml}$ prodigiosin decreased the NK cell activity by $31 \%$ and $41 \%$ at E:T ratios of $50: 1$ and $100: 1$, respectively. The NK cell activity at E:T ratio of $50: 1$ or 100:1 was further decreased $(45 \%, 55 \%)$ with increasing the prodigiosin concentration to $50 \mathrm{ng} / \mathrm{ml}$ (Fig. 2b). This indicates that prodigiosin can suppress the cytolytic activity of NK cells. Although significant inhibition of cytotoxicity by prodigiosin was observed in the present experiment, a complete suppression of NK activity was never obtained. This finding may reflect the existence of a subpopulation of NK cells that lack signaling via prodigiosin receptor-like molecule and are therefore resistant to prodigiosin-mediated suppression.

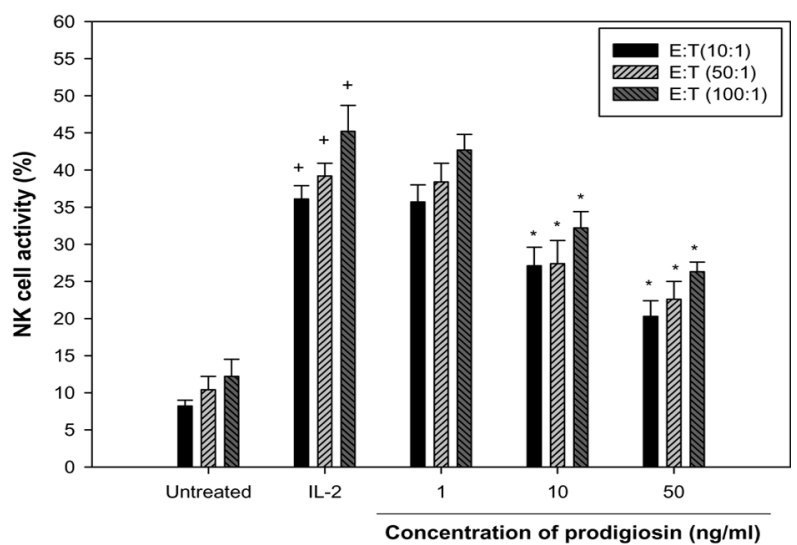

Fig. 2. The effect of prodigiosin on the NK cell cytotoxicity. Splenocytes were pretreated with various concentrations (1$50 \mathrm{ng} / \mathrm{ml}$ ) of prodigiosin for $2 \mathrm{~h}$ and co-cultured with target cells (YAC-1) for $20 \mathrm{~h}$ in medium supplemented with IL-2 (100 $\mathrm{U} / \mathrm{ml}$ ). The NK cell cytotoxicity was examined at $\mathrm{E}: \mathrm{T}$ ratios of $10: 1,50: 1$ and 100:I. The data represents the mean \pm SE of quadruplicate experiments. ${ }^{+} P<0.05$; significantly different from control (no treatment). ${ }^{*} \mathrm{P}<0.05$; significantly different from IL-2 treated. Experiments were repeated 3 times.

Macrophages have been shown to be important components of the host defenses against bacterial infections and tumor cells. Their ability to perform these various roles is related to their functional state (Adams and Hamilton, 1984). We next examined the effect of prodigi-

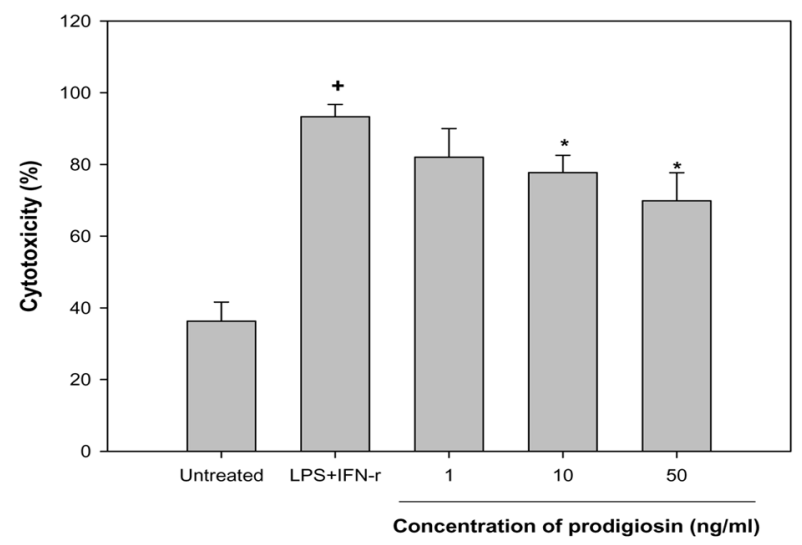

Fig. 3. Inhibitory effect of prodigiosin on tumoricidal activities of macrophages against B16 murine melanoma cells. Macrophages were pretreated with various concentrations (1- $50 \mathrm{ng} / \mathrm{ml}$ ) of prodigiosin for $2 \mathrm{~h}$ and co-cultured with target cells (B16) for $24 \mathrm{~h}$ in medium supplemented with LPS $(1 \mu \mathrm{g} / \mathrm{ml})$ plus IFN- $\gamma$ $(100 \mathrm{U} / \mathrm{ml})$. The macrophage tumoricidal activity was determined as described in Materials and Methods. The data shown are the results of an initial effector/target ratio of 10:1. The results are mean \pm S.E.M. of quintuplicates from a representative experiment. ${ }^{+} P<0.05$; significantly different from control (no prodigiosin treatment). ${ }^{*} \mathrm{P}<0.05$; significantly different from LPS + IFN- $\gamma$-treated. Experiments were repeated 3 times. 
osin on the function of macrophage.

To determine the effect of prodigiosin on the ability of macrophages to kill B16 melanoma cells that were TNF$\alpha$ or NO sensitive, macrophages exposed to prodigiosin were stimulated with LPS/IFN- $\gamma$. These cells were then incubated with target cells. At 10 and $50 \mathrm{ng} / \mathrm{ml}$, a significant reduction in macrophage-mediated cytotoxicity was noted as compared with control (Fig. 3). At $50 \mathrm{ng} / \mathrm{ml}$, prodigiosin treatment resulted in a $26 \%$ reduction under conditions of maximum activation with LPS/IFN- $\gamma$. This suppression of tumoricidal activity may be related to the decreased production of NO which has been known to be an important tumoricidal mediator, because our previous studies have shown that prodigiosin inhibits NO production and inducible nitric oxide synthase (iNOS) protein and mRNA expression but not the production of proinflammatory cytokines such as TNF- $\alpha$, IL-1 and IL-6 (Huh et al, 2006). These data also suggest that inhibitory effect of prodigiosin results from the suppression of p38 MAPK and JNK phosphorylation and NF-KB activation. However, since it is known that reactive oxygen intermediate $(\mathrm{ROI})$ is an important mediator for tumoricidal activity of macrophage (Ding et al., 1988), our data did not exclude the possibility that tumoricidal activity reduced by prodigiosin may be due to decrease of $\mathrm{ROI}$ production.

In conclusion, the data in these studies indicate that prodigiosin has a marked suppressive effect on splenocyte and macrophage activity in vitro and suggest that prodigiosin can regulate the reactivity of these cells in vivo in certain situations. The present study does not provide direct evidence that immunosuppression by prodiogsin occurs in vivo. It is reasonable, however, to propose that if prodigiosin acts in vivo as it does in vitro, inhibition of the immune response by this compound would be a possible therapeutic approach to the treatment of inflammatory diseases.

\section{ACKNOWLEDGEMENTS}

This work was supported by Korea Polar Research Institute, grant number PE08050.

\section{REFERENCES}

Adams, D. O, and Hamilton, T. A. (1984). The cell biology of macrophage activation. Annu. Rev. Immunol. 2, 283-318.

Bae, S. Y., Yim, J. H, Lee, H. K., and Pyo, S. (2006). Activation of murine peritoneal macrophages by sulfated exopolysaccharide from marine microalga Gyrodinium impudicum (strain KG03): involvement of the NF-KB and JNK pathway. Int. Immunopharmacol. 6, 473-484.
Ding, A. H., Nathan, C. F., and Stuehr, D. J. (1988). Release of reactive nitrogen intermediates and reactive oxygen intermediates from mouse peritoneal macrophages. Comparison of activating cytokines and evidence for independent production. J. Immunol. 141, 2407-2412.

Hahn, H. and Kaufmann, S. H. (1981). The role of cell-mediated immunity in bacterial infections. Rev. Infect. Dis. 3, 12211250.

Herberman, R. B. and Callewaert, D. M. (1985). Mechanisms of cytotoxicity by NK cells. Academic Press, London.

Huh, J, E, Yim, J. H., Lee, H. K., Moon, E. Y., Rhee, D. K., and Pyo, S. (2007). Prodigiosin isolated from Hahella chejuensis suppresses lipopolysaccharide-induced NO production by inhibiting p38 MAPK, JNK and NF-kappaB activation in murine peritoneal macrophages. Int. Immunopharmacol. 7, 1825-1833.

Jeong, H., Yim, J. H., Lee, C., Choi, S. H., Park, Y. K., Yoon, S. H, Hur, C. G., Kang, H. Y., Kim, D., Lee, H. H., Park, K. H., Park, S. H., Park, H. S., Lee, H. K., Oh, T. K., and Kim J. F. (2005). Genomic blueprint of Hahella chejuensis, a marine microbe producing an algicidal agent. Nucleic Acids Res. 33, 7066-7073.

Kataoka, T., Muroi, M., Ohkuma, S., Waritani, T., Magae, J., Takatsuki, A., Kondo, S., Yamasaki, M., and Nagai, K. (1995). Prodigiosin 25-C uncouples vacuolar type $\mathrm{H}+$ ATPase, inhibits vacuolar acidification and affects glycoprotein processing. FEBS Lett. 359, 153-159.

Kim, K. R., Son, E. W., Um SH, Kim, B. O., Rhee, D. K., and Pyo, S. (2003). Immune alterations in mice exposed to the herbicide simazine. J. Toxicol. Environ. Health A. 66, 11591173.

Lee, H. K., Chun, J., Moon, E. Y., Ko, S. H., Lee, D. S., Lee, H. S., and Bae, K. S. (2001). Hahella chejuensis gen. nov., sp. nov., an extracellular-polysaccharide-producing marine bacterium. Int. J. Syst. Evol. Microbiol. 51, 661-666.

Mosmann, T. (1983). Rapid colorimetric assay for cellular growth and survival: application to proliferation and cytotoxicity assays. J. Immunol. Methods 65, 55-63.

Nakamura, A., Nagai, K., Ando, K., and Tamura, G. (1986). Selective suppression by prodigiosin of the mitogenic response of murine splenocytes. J. Antibiot. (Tokyo). 39, 1155-1159.

Pandey, R., Chanderb, R., and Sainisa, K. B. (2003). A novel prodigiosin-like immunosuppressant from an alkalophilic Micrococcus sp. Int. Immunopharmacol. 3, 159-167.

Songia, S., Mortellaro, A., Taverna, S., Fornasiero, C., Scheiber, E. A., Erba, F., Colotta, F., Mantovani, A., Isetta, A. M. and Golay, J. (1997). Characterization of the new immunosuppressive drug undecylprodigiosin in human lymphocytes. J. Immunol. 158, 3987-3995.

Um, S. H., Rhee, D. K., and Pyo, S. (2002). Involvement of protein kinase $\mathrm{C}$ and tyrosine kinase in tumoricidal activation of macrophage induced by Streptococcus pneumoniae type II capsular polysaccharide. Int. Immunopharcol. 2, 129-137.

Verstovsek, S., Maccubbin, D., and Mihich, E. (1992). Tumoricidal activation of murine resident peritoneal macrohages by interleukin 2 and tumor necrosis factor. Cancer Res. 52, 3880-3885. 